\title{
SYNTHESIS AND ABSORPTION PROPERTIES OF NOVEL NA SPECIFIC ADSORBENT Li ${ }_{1+X} \operatorname{La}_{X} \mathrm{Zr}_{2-X}\left(\mathrm{Po}_{4}\right)_{3}$
}

\author{
JIAN-ZHI SUN \\ Department of Chemistry, Dezhou University, shandong Dezhou 253023, P. R. China;
}

(Received: December 17, 2008 - Accepted: June 2, 2008)

\begin{abstract}
A novel kind of adsorbent $\mathrm{Li}_{1+\mathrm{La}} \mathrm{Zr}_{2}\left(\mathrm{PO}_{4}\right)_{3}$ was synthesized by solid state reaction method. The influence of the content of doping lanthanum on the adsorbent $\mathrm{Li}_{1+x} \mathrm{La}_{x} \mathrm{Zr}_{2-x}\left(\mathrm{PO}_{4}\right)_{3}$ was investigated by XRD and FTIR spectra while the morphology of powders was observed by SEM. The investigation of the adsorption properties showed that the adsorbent can selectively adsorb sodium with the adsorption capacity of $49.83 \mathrm{mg} / \mathrm{g}$. The optimum conditions of adsorption are at $\mathrm{pH} 10.0 \sim 11.0$ in $\mathrm{LiCl}$ solution.
\end{abstract}

Keywords: $\mathrm{LiCl}, \mathrm{Li}_{1+x} \mathrm{La}_{x} \mathrm{Zr}_{2-x}\left(\mathrm{PO}_{4}\right)_{3}$, adsorbent, separation.

\section{INTRODUCTION}

Lithium chloride is an industrial raw material, from which lithium compounds and in particular metallic lithium are produced. To make further processing of the lithium chloride more economic and efficient, it is very necessary to provide the raw material as pure as possible. The presence of very small quantities of sodium in the lithium metal will make it highly reactive and much different in properties than purity lithium metal. So as the raw material of $\mathrm{LiCl}$ it is required in low content of $\mathrm{Na}$.

The ordinary separation method is to extract sodium with isopropanol ${ }^{1}$, which not only consumes substantive organic solvent, but also is serious harm to environment. The adsorption method is briefly and feasible in theory, but the synthesis of an applicable adsorbent is a big problem. In the decades, antimonic and polyantimonic acid have been studied in the field ${ }^{2}$, but it failed to practice because of the high cost. At present, to meet the rapidly increasing demand on lithium chloride, especially the high pure lithium chloride, it is urgent to remove $\mathrm{Na}^{+}$in the produce of the high pure lithium chloride.

NASICON(Acronym of natrium superionic conductor) materials present interesting sensitive and selective properties against alkaline cations due to their structure. $\mathrm{Li}_{1+x} \mathrm{Al}_{x} \mathrm{Ti}_{2-x}\left(\mathrm{PO}_{4}\right)_{3}$ possesses the NASICON-type structure, is especially good candidates to determine alkaline ions concentrations in solution or to separate monovalent cations from a mixture of multivalent ions $\mathrm{s}^{3,4}$.

$\mathrm{Li}_{1+x} \mathrm{Al}_{x} \mathrm{Ti}_{2-x}\left(\mathrm{PO}_{4}\right)_{3}$ composed of both $\mathrm{MO}_{6}$ octahedra and $\mathrm{PO}_{4}$ tetrahedra which are linked by their corners to form a opened-three-dimension (3D) network structure. The resulted structure consists of Type I sites(octahedral Ocoordination) and Type II sites(10-fold O-coordination) for the mobile $\mathrm{Li}$ ions to occupy. $\mathrm{Li}^{+}$ions move from one site to another passing through bottle-necks defined by the anionic skeleton $\left[\mathrm{Al}_{x} \mathrm{Ti}_{2-x}\left(\mathrm{PO}_{4}\right)_{3}\right]^{(1+x)}$.

$\mathrm{Zr}\left(4 \mathrm{~d}\right.$ series) and $\mathrm{Ti}(3 \mathrm{~d} \text { series) })^{x}$ which belongs to same group of elements in the periodic table, have similar chemical properties. Lanthanide series are widely used in the field of catalysts, functional materials and new material ${ }^{5}$. The valence of La and Al mainly is +3 , Then, the attempt was done in this paper to improve the adsorption performance by substitute $\mathrm{La}$ and $\mathrm{Zr}$ for $\mathrm{Al}$ and Ti.

The results showed that $\mathrm{Li}_{1+x} \mathrm{La}_{x} \mathrm{Zr}_{2-x}\left(\mathrm{PO}_{4}\right)_{3}$ show higher absorption capacities towards $\mathrm{Na}^{+}$. The exchange capacity of $\mathrm{Li}_{14} \mathrm{La}_{04} \mathrm{Zr}_{16}\left(\mathrm{PO}_{4}\right)_{3}$ was $49.83 \mathrm{mg} / \mathrm{g}$, which is four times of $\mathrm{Li}_{14} \mathrm{Al}_{04} \mathrm{Ti}_{16}\left(\mathrm{PO}_{4}\right)_{3}$. Compared with other methods, the novel Na specific adsorbent of $\left.\mathrm{Li}_{1+} \mathrm{La} \mathrm{Zr}_{2-(} \mathrm{PO}_{4}\right)_{3}$ described here is a simpler and more convenient way to remove $\mathrm{Na}^{+}$from LiCl solution which suggest the promising application.

\section{EXPERIMENTAL}

1

$\mathrm{Li}_{1+x} \mathrm{La} \mathrm{Zr}_{2-x}\left(\mathrm{PO}_{4}\right)_{3}(\mathrm{x}=0.0 \sim 1.0)$ was prepared by solid state reaction of $\mathrm{Li}_{2} \mathrm{CO}_{3}$ (A. R. R., $\mathrm{ZrO}_{2}$ (A.R.), $\mathrm{La}_{2} \mathrm{O}_{3}$ (A.R.), $\mathrm{NH}_{4} \mathrm{H}_{2} \mathrm{PO}_{4}$ (A.R.), $\mathrm{C}_{6} \mathrm{H}_{4}$ (A.R.). The starting materials were weighed in stoichiometric amounts and homogenized using a mixer. The mixture was put in a tubular furnace and had been heated for $6 \mathrm{~h}$ at $600{ }^{\circ} \mathrm{C}$ to decompose the oxalate and the phosphate. The powder was cooled down to room temperature and then pressed into $\Phi 10 \mathrm{~mm}$ pellets under $20 \mathrm{MPa}$. After grinding and homogenization, the mixture was transferred to the furnace and annealed at $1000^{\circ} \mathrm{C}$ for $20 \mathrm{~h}$.

\section{Characterization and Measurements of adsorption capacity}

2.1 DSC-TGA

The thermal analysis (DSC-TGA) was carried out by employing a TA SDT Q600. The samples were heated to $1000^{\circ} \mathrm{C}$ at a heating rate of $10^{\circ} \mathrm{C} / \mathrm{min}$ under nitrogen atmosphere.

$2.2 X R D$

The X-ray diffraction(XRD) was performed at room temperature on a Rigaku D/max-3B X-Ray diffractometer, the X-ray beam was nickel-filtered $\mathrm{Cu} K \alpha(\lambda=0.15406 \mathrm{~nm})$ radiation operated at $40 \mathrm{kV}$ and $30 \mathrm{~mA}$; and the data were collected from $3^{\circ}$ to $80^{\circ}(2 \theta)$ at a scanning rate of $5 \% \mathrm{~min}$.

\subsection{FTIR}

The Fourier transform infrared(FTIR) spectra were recorded on a Thermo Nicolet Nexus in the wave number range of $4000-400 \mathrm{~cm}^{-1}$. Care was taken to press all the $\mathrm{KBr}$ pellets under the same conditions to minimize any effect of pressure on peak frequencies for the power samples.

2.4 Measurements of adsorption capacity

$1.0 \mathrm{~g}$ diffraction patterns of $\mathrm{Li}_{1+x} \mathrm{La}_{x} \mathrm{Zr}_{2-x}\left(\mathrm{PO}_{4}\right)_{3}$ samples were added to 100 g LiCl solution contained $0.06 \% \mathrm{Na}^{+}$. The concentration of $\mathrm{Na}^{+}$in solution is measured after stirring the solution for $10 \mathrm{~h}$ at $\mathrm{pH} 11.0$. The adsorption capacity of diffraction patterns of $\mathrm{Li}_{1.4} \mathrm{La}_{0.4} \mathrm{Zr}_{1.6}\left(\mathrm{PO}_{4}\right)_{3}$ samples was carried out at different $\mathrm{pH}$ value and different content of doping lanthanum.

\section{RESULTS AND DISCUSSION}

Fig. 1 shows DSC-TGA curves of the raw material. There are four endothermic peaks at $121{ }^{\circ} \mathrm{C} 204{ }^{\circ} \mathrm{C} 310{ }^{\circ} \mathrm{C}$ and $341^{\circ} \mathrm{C}$ in DSC curves. TG curve revealed the mass loss of $24.95 \%$ which occurred at $20{ }^{\circ} \mathrm{C}$ to $600{ }^{\circ} \mathrm{C}$, while no change in weight was found from $600 \sim 1000{ }^{\circ} \mathrm{C}$. The following reaction can be expected to have mass loss of $24.52 \%$ :

$$
\begin{gathered}
(1+x) \mathrm{Li}_{2} \mathrm{CO}_{3}+x \mathrm{La}_{2} \mathrm{O}_{3}+(4-2 x) \mathrm{ZrO}_{2}+6 \mathrm{NH}_{4} \mathrm{H}_{2} \mathrm{PO}_{4}= \\
2 \mathrm{Li}_{1+x} \mathrm{La}_{x} \mathrm{Zr}_{2-x}\left(\mathrm{PO}_{4}\right)_{3}+9 \mathrm{H}_{2} \mathrm{O}+6 \mathrm{NH}_{3}+(1+x) \mathrm{CO}_{2}
\end{gathered}
$$

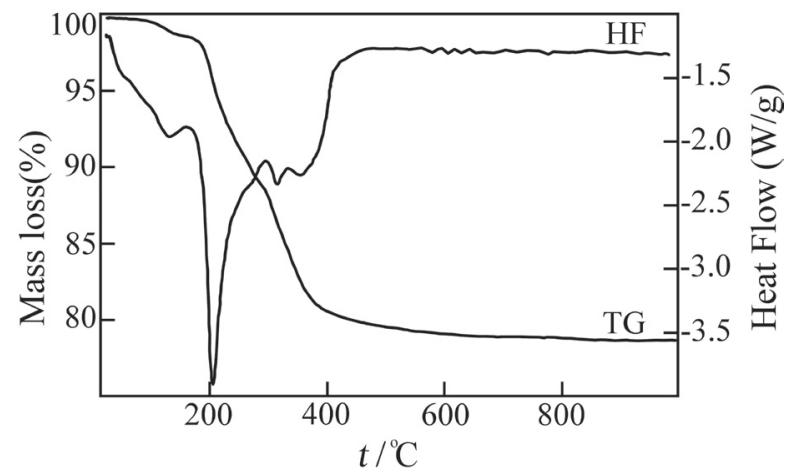

Fig. 1 DSC-TGA curves of the raw material

The phase evolution of diffraction patterns $\mathrm{Li}_{1+x} \mathrm{La}_{x} \mathrm{Zr}_{2-x}\left(\mathrm{PO}_{4}\right)_{3}$ were studied by the XRD analysis (Fig. 2).The substitution of $\mathrm{La}^{3+}$ for $\mathrm{Zr}^{4+}$ was tried 
synthetically to observe the change of the crystalline structure. The $\mathrm{LiZr}_{2}\left(\mathrm{PO}_{4}\right)_{3}$ structure was retained in the solid solution range at $x \leq 0.4$. It was indexed in the rhombohedral system with lattice: rhomb-centered, space group $\mathrm{R} \overline{3} \mathrm{c}$ and the cell parameters: $\mathrm{a}=0.88077 \mathrm{~nm}, \mathrm{~b}=0.88077 \mathrm{~nm}, \mathrm{c}=2.2715 \mathrm{~nm}, \alpha=90^{\circ}, \beta=90^{\circ}$, $\gamma=120^{\circ}$. It showed that trifle $\mathrm{La}^{3+}$ dopant did not affect the structure of the material. Some additional diffraction peaks appeared in the XRD patterns when $\mathrm{x}$ is above 0.4 .

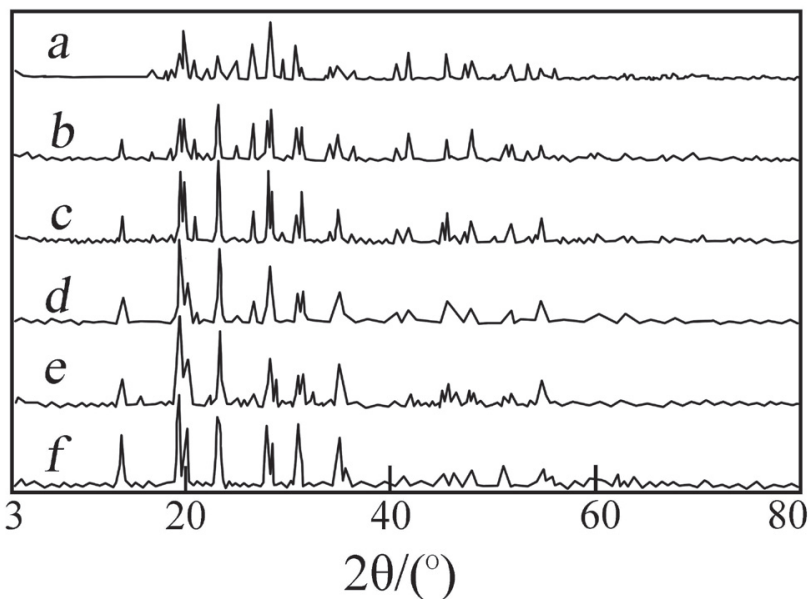

Fig. 2 The XRD patterns of $\mathrm{Li}_{1+x} \mathrm{La}_{x} \mathrm{Zr}_{2-x}\left(\mathrm{PO}_{4}\right)_{3}$ samples f. $x=0$.

Molar fraction of dopants: $a . x=1 ; b . x=0.8 ; c . x=0.6 ; d . x=0.4 ;$ e. $x=0.2$;

The IR spectra of diffraction patterns $\mathrm{Li}_{1+x} \mathrm{La}_{\mathrm{r}} \mathrm{Zr}_{2-x}\left(\mathrm{PO}_{4}\right)_{3}$ are shown in Fig.3. The shape of IR spectrum weakened along with the gradual augmentation of $\mathrm{La}^{3+}$. It showed the augmentation of $\mathrm{La}^{3+}$ leaded to the aberration of $\mathrm{Li}_{1+x} \mathrm{La} \mathrm{Zr}_{2}$. $\left(\mathrm{PO}_{4}\right)_{3}$ crystal lattice and the lessening of the component of crystalloid ${ }^{6,7}$.

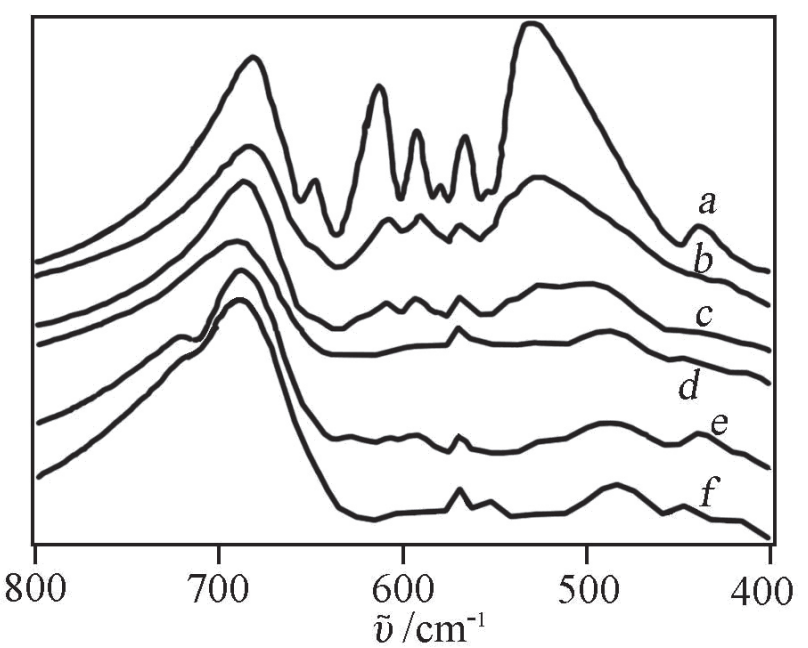

Fig.3 FTIR spectra of $\mathrm{Li}_{1+x} \mathrm{La}_{x} \mathrm{Zr}_{2-x}\left(\mathrm{PO}_{4}\right)_{3}$ f. $x=1$.

Molar fraction of dopants: $a . x=0 ; b . x=0.2 ; c . x=0.4 ; d . x=0.6$; e. $x=0.8$;

Keeping other variables constant (Table 1), the adsorption capacity of $\mathrm{Li}_{14} \mathrm{La}_{2} \mathrm{Zr}_{16}\left(\mathrm{PO}_{4}\right)_{3}$ towards $\mathrm{Na}^{+}$was measured at different $\mathrm{pH}$ values. It was found that the adsorption capacity was quantitatively retained in the $\mathrm{pH}$ range of $10.0 \sim 11.0$. So the optimum $\mathrm{pH}$ value of adsorption was from 10.0 to 11.0 in $\mathrm{LiCl}$ solution.

Table 1. Influence of $\mathrm{pH}$ on the adsorption capacity $\mathrm{Na}^{+}$of $\mathrm{Li}_{1.4} \mathrm{La}_{0.4} \mathrm{Zr}_{1.6}\left(\mathrm{PO}_{4}\right)_{3}$

\begin{tabular}{|l|c|c|c|c|c|c|}
\hline \multicolumn{1}{|c|}{$\mathrm{pH}$} & 5 & 7 & 9 & 10 & 11 & 12 \\
\hline $\begin{array}{l}\text { Adsorption } \\
\text { capacity }\left(\mathrm{mg} \cdot \mathrm{g}^{-1}\right)\end{array}$ & 1.20 & 8.37 & 15.41 & 40.25 & 49.83 & 30.06 \\
\hline
\end{tabular}

The adsorption capacity of diffraction patterns of $\mathrm{Li}_{1+\mathrm{L}} \mathrm{La}_{\mathrm{Zr}}\left(\mathrm{ZO}_{4}\right)_{3}$ samples was shown in Table 2. The adsorption capacity of $\operatorname{LiZr}_{2}\left(\mathrm{PO}_{4}\right)_{3}$ to $\mathrm{Na}^{+}$was $5.16 \mathrm{mg} / \mathrm{g}$ and the $\mathrm{La}^{3+}$ dopant considerably improved its specific adsorption capacity to $\mathrm{Na}^{+}$. When $\mathrm{x}=0.4$, the adsorption capacity reached the maximum value of $49.83 \mathrm{mg} / \mathrm{g}$. So the optimum dopant quantity of $\mathrm{La}^{3+}$ was $\mathrm{x}=0.4$.

After adding $\mathrm{La}$ in $\mathrm{Li}_{1+x} \mathrm{La}_{x} \mathrm{Zr}_{2-x}\left(\mathrm{PO}_{4}\right)_{3}$ crystal structure, $\mathrm{Zr}$ was replaced by $\mathrm{La}$ and $\mathrm{Li}$, which produced negative charge among crystal layers and made La and Li becoming two active centers and benefited to adsorb some cation. However, the excessive La would destroy the structure of $\mathrm{LiZr}_{2}\left(\mathrm{PO}_{4}\right)_{3}$ with forming $\mathrm{Li}_{3} \mathrm{PO}_{4}$ and $\mathrm{LaPO}_{4}$, while $\mathrm{Na}$ can not be adsorbed. The idiographic mechanism needs to be further studied.

Table 2 The adsorption capacity of diffraction patterns of $\mathrm{Li}_{1+x} \mathrm{La}_{x} \mathrm{Zr}_{2}$ ${ }_{x}\left(\mathrm{PO}_{4}\right)_{3}$

\begin{tabular}{|c|c|c|c|c|c|}
\hline \multirow{2}{*}{$x$} & \multicolumn{5}{|c|}{ Adsorption capacity $\left(\mathrm{mg} \cdot \mathrm{g}^{-1}\right)$} \\
\cline { 2 - 6 } & 1 & 2 & 3 & 4 & Average \\
\hline 0 & 4.15 & 5.67 & 4.39 & 6.10 & 5.16 \\
\hline 0.2 & 41.40 & 39.13 & 39.71 & 40.78 & 40.27 \\
\hline 0.4 & 49.05 & 51.77 & 50.74 & 47.63 & 49.83 \\
\hline 0.6 & 36.08 & 38.26 & 36.83 & 35.82 & 36.75 \\
\hline 0.8 & 15.94 & 19.40 & 18.72 & 17.59 & 17.93 \\
\hline 1.0 & 11.67 & 10.99 & 8.46 & 10.12 & 10.56 \\
\hline
\end{tabular}

\section{CONCLUSION}

In this study, we synthesized a novel kind of adsorbent $\mathrm{Li}_{1+x} \mathrm{La}_{x} \mathrm{Zr}_{2-x}\left(\mathrm{PO}_{4}\right)_{3}$ by solid state reaction method. The trifle $\mathrm{La}^{3+}$ dopant did not affect the structure of the material but considerably improved its specific adsorption capacity towards $\mathrm{Na}^{+}$. It could be used to remove $\mathrm{Na}^{+}$from lithium chloride. The results of adsorbing test showed that its exchange capacity was high with the maximum value of $49.83 \mathrm{mg} / \mathrm{g}$ at $\mathrm{x}=0.4, \mathrm{pH}=10.0 \sim 11.0$. That method was a simpler and more convenient way to remove $\mathrm{Na}^{+}$from lithium chloride solution.

\section{REFERENCES AND ACKNOWLEDGMENTS}

1. Brown, Patrick M., et al, U S Patent 4,980,136, (1990)

2. Deberitz, Jurgen., et al, U S Patent 6,063,345, (2000)

3. Losilla E.R., Aranda M.A.G., et al , Chemistry of Materials, 12, 2134 , (2000)

4. A. Puigsegur, R. Mouazer, et al, Separation and Purification Technology, 32, 51, (2003)

5. Barre, M.; Le Berre, F.; Crosnier-Lopez, M. P.; et al, Chem. Mater. 18, $5486,($ 2006)

6. Yu X. B., Wang G. H., et al, Acta Chm. Sin, 58, 548. (2000)

7. Lin X. Y., Huang C. J., et al, Acta Phy. Sin, 53, 1558.(2004) This work was supported by the National Key Technologies R\&D Program of China during the 10th Five-Year Plan Period (No.2004BA602B-01) and the Key Technologies R \& D Program of Qinghai province(No.2005-G173). 